\title{
SIADH is only an Atypical Clinical Feature in a Patient with Prolactinoma
}

\author{
Tomoyuki Saito ${ }^{1}$, Yasutaka Watanabe ${ }^{1}$, Miho Yuzawa ${ }^{1}$, Takako Saito ${ }^{1}$, \\ Hiroyuki Tamemoto ${ }^{1}$, Hisashi Suzuki ${ }^{2}$, Gen Kusaka ${ }^{2}$, Yoshio Omori ${ }^{2}$, \\ Soji Shinoda ${ }^{2}$, Masanobu Kawakami ${ }^{1}$ and San-e Ishikawa ${ }^{1}$
}

\begin{abstract}
A 50-year-old man was admitted to determine the pathogenesis of hyponatremia. He had a poor appetite and was easily fatigued. Physical findings showed that he was conscious and alert. He had neither dry skin or tongue, nor pretibial edema. Laboratory data revealed that the serum sodium level was $110 \mathrm{mmol} / \mathrm{l}$; plasma osmolality, $238 \mathrm{mmol} / \mathrm{kg}$; and urinary osmolality, $417 \mathrm{mmol} / \mathrm{kg}$. Plasma arginine vasopressin was $0.5 \mathrm{pg} / \mathrm{ml}$ despite plasma osmolality of $242 \mathrm{mmol} / \mathrm{kg}$. An acute water load showed impaired water excretion, as percent excretion of water load was $30 \%$ and minimal urinary osmolality was $642 \mathrm{mmol} / \mathrm{kg}$. Serum prolactin was $254 \mathrm{ng} / \mathrm{ml}$, and anterior pituitary hormones of ACTH, TSH and GH were in the normal ranges. Brain magnetic resonance imaging (MRI) showed a pituitary tumor with a size of $20 \times 22 \times 21 \mathrm{~mm}$ and it pushed a pituitary stalk upward. Immunohistochemistry revealed prolactinoma. After the adenomectomy, serum sodium level has been kept normal with free access to water intake. The present study indicates that syndrome of inappropriate secretion of antidiuretic hormone (SIADH) is manifested in association with pituitary macroadenoma of prolactinoma.
\end{abstract}

Key words: SIADH, prolactinoma, hyponatremia, pituitary macroadenoma, normal function of pituitaryadrenal axis

(DOI: 10.2169/internalmedicine.46.6422)

\section{Introduction}

The concept of the syndrome of inappropriate secretion of antidiuretic hormone (SIADH) was established by Bartter and Schwartz (1). The criteria include hyponatremia, hypoosmolality, hypertonic urine with neither dehydration nor edema, and no dysfunction of kidney and adrenal gland. There are two sources of arginine vasopressin (AVP) in SIADH, including either ectopic production of AVP in lung cancer, pancreatic cancer and others, or increased central secretion of AVP from the posterior pituitary gland due to disorders of the central nervous system and lung, or drugs (2, 3). The mechanism of AVP secretion from the posterior pituitary is not known in disorders of the central nervous system.
Pituitary macroadenoma occupying intrasellar space can be accompanied by hyponatremia. In most clinical settings hyponatremia is closely related to secondary hypopituitarism, particularly dysfunction of the pituitary-adrenal axis (4-7). Such a hyponatremia is included in the category of euvolemic hyponatremia, a disorder distinct from SIADH. However, there are a few case reports showing hyponatremia in patients with pituitary macroadenoma whose pituitary function is normal (8-10). The increased secretion of AVP could be due to local mechanical stress, thus producing SIADH.

In the present study we encountered a patient with macroadenoma. He manifested hyponatremia without any sign or symptom of prolactinoma itself. We evaluated the possible mechanisms of non-suppressible release of AVP in this patient.

\footnotetext{
${ }^{1}$ Department of Medicine, Jichi Medical University Omiya Medical Center, Saitama and ${ }^{2}$ Department of Neurological Surgery, Jichi Medical University Omiya Medical Center, Saitama

Received for publication December 11, 2006; Accepted for publication February 4, 2007

Correspondence to Dr. San-e Ishikawa, saneiskw@jichi.ac.jp
} 
Table 1. The Responses of Anterior Pituitary Hormones to a Mixture of CRH, TRH, GRH and LH-RH

Time (min)

\begin{tabular}{lcccccc} 
& 0 & 15 & 30 & 60 & 90 & 120 \\
\hline GH (ng/ml) & 0.67 & & 11.01 & 14.95 & 11.60 & 7.98 \\
LH (mIU/ml) & 0.7 & & 2.0 & 2.2 & 2.0 & 1.9 \\
FSH (mIU/ml) & 2.1 & & 3.0 & 3.4 & 3.5 & 3.8 \\
ACTH (pg/ml) & 56.2 & 46.8 & 45.6 & 46.4 & 34.5 & 27.2 \\
TSH (IU/ml) & 3.4 & & 19.6 & 15.4 & 12.3 & 9.9 \\
\hline
\end{tabular}

\section{Case Report}

A 50-year-old man had poor appetite and easy fatigability for the previous 1-2 weeks. He visited a physician and was pointed out to have severe hyponatremia of $110 \mathrm{mmol} / \mathrm{l}$. According to the suggestion of the physician, he was admitted to Jichi Medical University Omiya Medical Center to further elucidate the pathogenesis of hyponatremia in April 2004. Physical findings were height, $162 \mathrm{~cm}$; body weight, 64.2 $\mathrm{kg}$; blood pressure, $112 / 74 \mathrm{mmHg}$ without postural change; and pulse rate, 70/min with regular rhythm. He was conscious and alert. He was not thirsty, and had neither dry skin or tongue, nor pretibial edema. There was no galactorrhea. Neurological examination showed no abnormal findings, including no disturbance of visual field. He did not complain of any reduction in his libido.

Laboratory findings showed white blood cells were $11,800 / \mathrm{cmm}$; red blood cells, $385 \times 10^{4} / \mathrm{cmm}$; hemoglobin, $12.0 \mathrm{~g} / \mathrm{dl}$; hematocrit, $33.2 \%$; and platelets, $43.0 \times 10^{4} / \mathrm{cmm}$. Serum sodium $(\mathrm{Na})$ was $110 \mathrm{mmol} / \mathrm{l}$; potassium, $4.5 \mathrm{mmol} / \mathrm{l}$; and chloride, $84 \mathrm{mmol} / \mathrm{l}$. Blood urea nitrogen was $7 \mathrm{mg} / \mathrm{dl}$; serum creatinine, $0.56 \mathrm{mg} / \mathrm{dl}$; and uric acid, $2.1 \mathrm{mg} / \mathrm{dl}$. Plasma osmolality (Posm) was $238 \mathrm{mmol} / \mathrm{kg}$ and urinary osmolality (Uosm), $417 \mathrm{mmol} / \mathrm{kg}$. Urinary $\mathrm{Na}$ excretion was $115 \mathrm{mmol} / \mathrm{day}$. Urine volume ranged from 1,300 to 1,740 $\mathrm{ml} /$ day. Plasma AVP level was $0.5 \mathrm{pg} / \mathrm{ml}$ despite the Posm of $242 \mathrm{mmol} / \mathrm{kg}$. An acute oral water load test was carried out on the 11th hospitalized day when serum $\mathrm{Na}$ level was $140 \mathrm{mmol} / \mathrm{l}$. The percent excretion of water load was $30 \%$ and minimal Uosm was $642 \mathrm{mmol} / \mathrm{kg}$, indicating severe impaired water excretion. Plasma renin activity was 0.1 $\mathrm{ng} / \mathrm{ml} / \mathrm{h}$ and plasma aldosterone concentration was $100 \mathrm{pg} /$ ml. Serum prolactin level was $254 \mathrm{ng} / \mathrm{ml}$. Plasma ACTH level was $56.2 \mathrm{pg} / \mathrm{ml}$, with serum cortisol of $24.4 \mu \mathrm{g} / \mathrm{dl}$. Serum TSH was $3.4 \mu \mathrm{U} / \mathrm{ml}$; serum $\mathrm{GH}, 0.67 \mathrm{ng} / \mathrm{ml}$; serum $\mathrm{LH}$, $0.7 \mathrm{mIU} / \mathrm{ml}$; and serum $\mathrm{FSH}, 2.1 \mathrm{mIU} / \mathrm{ml}$. Serum free $\mathrm{T}_{4}$ was $0.56 \mathrm{ng} / \mathrm{dl}$; serum free $\mathrm{T}_{3}, 2.73 \mathrm{pg} / \mathrm{ml}$; and serum IGF-
1, $103.7 \mathrm{ng} / \mathrm{ml}$. Serum prolactin level remained high after the administration of $2.5 \mathrm{mg}$ bromocriptine. Basal level of serum PRL was $304.0 \mathrm{ng} / \mathrm{ml}$, and its minimal value was $78.2 \mathrm{ng} / \mathrm{ml} 6$ hours after the oral administration of bromocriptine. Endocrinological challenge tests for anterior pituitary hormones are summarized in Table 1. Intravenous administration of $500 \mu \mathrm{g}$ TRH further increased serum prolactin from 185 to $206 \mathrm{ng} / \mathrm{ml}$. There were normal responses of TSH and GH to TRH and GRH, but the secretion of LH and FSH in response to LH-RH was blunted. Basal level of plasma ACTH was normal, but its response to CRH was not found. Brain magnetic resonance imaging (MRI) showed a pituitary tumor with a size of $20 \times 22 \times 21 \mathrm{~mm}$. It pushed the pituitary stalk and posterior pituitary gland upward, and the pituitary stalk was shifted to the left with a high signal, indicating the damming-up phenomenon (Fig. 1) (11).

\section{Clinical course}

On admission he had severe hyponatremia of $110 \mathrm{mmol} / \mathrm{l}$. There was neither edema nor dehydration. Posm was 238 $\mathrm{mmol} / \mathrm{kg}$, whereas Uosm was elevated to $417 \mathrm{mmol} / \mathrm{kg}$. Adrenal and renal functions were normal. These findings properly indicated SIADH according to the criteria of Bartter and Schwartz (1). As serum Na level was as low as 116 $\mathrm{mmol} / \mathrm{l}, 3 \% \mathrm{NaCl}$ was initially infused, and serum $\mathrm{Na}$ level was increased to $126 \mathrm{mmol} / \mathrm{l}$. Thereafter, water restriction (15 ml/kg body weight per day) was started, and serum $\mathrm{Na}$ levels had been remained at 139-143 mmol/l. In June 2004 prolactinoma was removed by transsphenoidal adenomectomy. The histological study is shown in Fig. 2. Basophilic cells were found to have a follicular-like pattern in the tumor tissue on hematoxylin-eosin staining. Immunohistochemistry showed that PRL was abundantly stained in the tumor cells. These studies confirmed that the pituitary adenoma was prolactinoma. There was no occurrence of postoperative diabetes insipidus in the patient. After the operation, the maneuver of water restriction was released, but hyponatremia had never recurred for the subsequent 2 years 

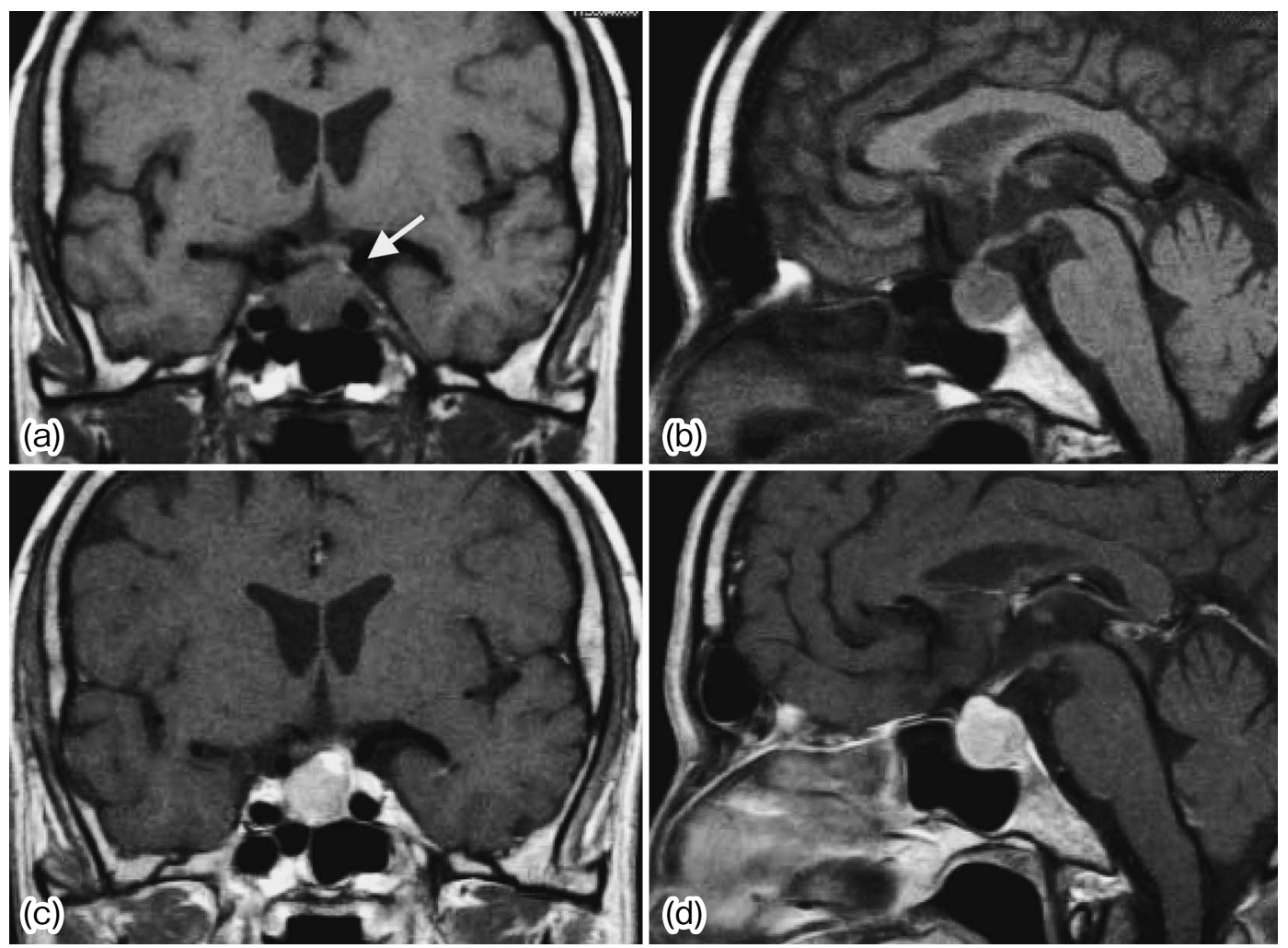

Figure 1. Coronal and sagittal views of MRI in a patient with prolactinoma. Arrows show the damming-up phenomenon. Plain MRI: (a) (b), gadolinium-enhanced MRI (c) (d).
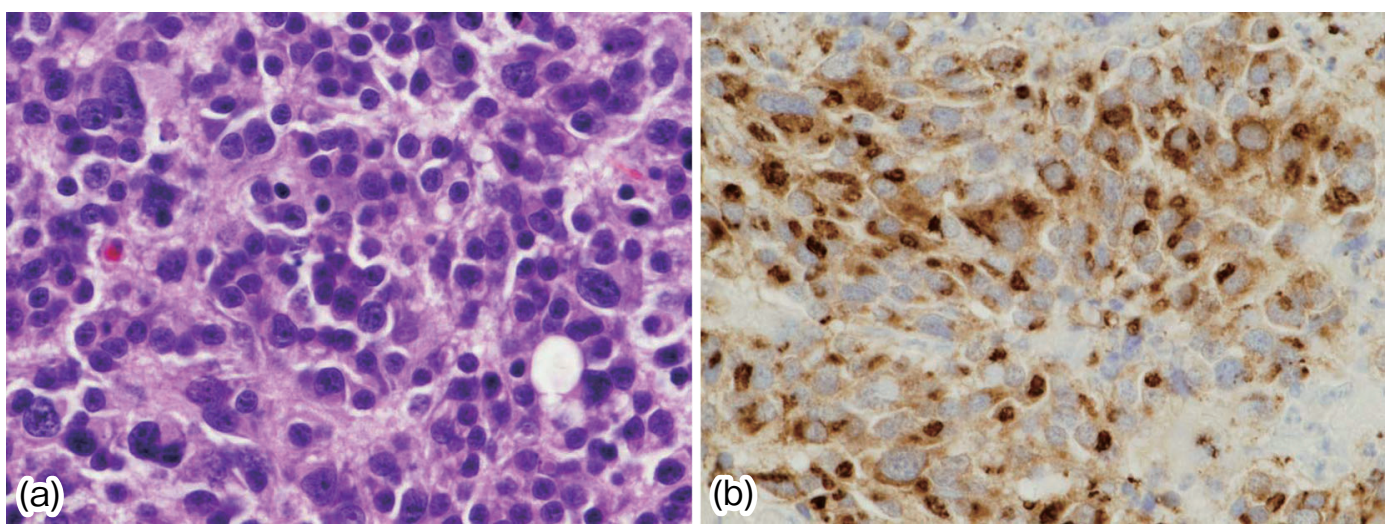

Figure 2. Histological study of prolactinoma. Hematoxylin-Eosin staining. Magnification $\times 400$ (a). Immunohistochemical study of prolactinoma using anti-serum against human prolactin. Magnification; $\times 400$ (b).

and 5 months after the operation. A month after the operation MRI showed incomplete resection of the pituitary tumor and serum PRL level remained as high as $71.0 \mathrm{ng} / \mathrm{ml}$. Six months after the operation, serum PRL level was still $91.0 \mathrm{ng} / \mathrm{ml}$. Thus, he has been treated with $0.25 \mathrm{mg}$ cabergoline since March 2005, and his serum PRL level was decreased to $12.2 \mathrm{ng} / \mathrm{ml}$ in May 2006.

\section{Discussion}

In the present patient hyponatremia was initially found, and the following examinations verified large pituitary adenoma which occupied intrasellar space. Immunohistochemical study showed that pituitary adenoma was prolactinoma. $\mathrm{He}$ had no typical symptoms and signs related to prolactinoma. Endocrinological study showed normal function of anterior pituitary gland except for hyperprolactinemia 
and impaired secretion of gonadotropin. Physical examination revealed neither edema nor dehydration. There were hyponatremia and hypoosmolality with the elevation of urinary osmolality. An acute water load test clarified impaired water excretion. The patient was diagnosed as having SIADH (1). The intrasella-occupied prolactinoma pushed the pituitary stalk and posterior pituitary upward. MRI showed the damming-up phenomenon (11), which means that the high signal was depicted only in the pituitary stalk and it disappeared in the posterior pituitary gland. The dislocation of the pituitary stalk and neurohypophysis could result in an inappropriate secretion of AVP. However, it is a unlikely possibility that hyperprolactinemia caused the impaired water excretion, because of the following reasons. First, there was a non-suppressible level of plasma AVP despite hypoosmolality. Second, water restriction therapy normalized the serum $\mathrm{Na}$ levels.

SIADH associated with pituitary tumor is not a common disorder among various pathogenesis of SIADH. There are only four patients including the present patient reported in the literature (8-10). We know of a number of subjects having large pituitary tumor occupying the sella turcica, but severe hyponatremia independent of dysfunction of pituitaryadrenal axis is infrequent. A pituitary tumor of greater than
$20 \mathrm{~mm}$ in diameter becomes dislocated and then compresses the pituitary stalk and neurohypophysis, but it may not influence the hypothalamus which has the cell body of AVPproducing neurons. The augmentation of AVP release could be related to the local, non-specific mechanical stress on the axonal terminal of AVP neurons, and the excessive release of AVP could be transient. Taken together, the duration of hyponatremia is limited and hyponatremia is occasionally discovered. It is of value to know that the inappropriate secretion of AVP occurs in association with pituitary macroadenoma.

After the infusion of hypertonic saline at the hospitalization, the serum $\mathrm{Na}$ level was easily maintained by only water restriction. After the adenomectomy, water restriction was released, and serum $\mathrm{Na}$ levels were kept in normal range. The damming-up phenomenon was taken out, and the high signal of the posterior pituitary was found on MRI. These findings again suggested the stimulation of AVP release at the pituitary stalk and posterior pituitary, but not at the hypothalamus.

The present study was supported by the grant from the Ministry of Health, Labor and Welfare of Japan.

\section{References}

1. Bartter FC, Schwartz WB. The syndrome of inappropriate secretion of antidiuretic hormone. Am J Med 42: 790-806, 1967.

2. Ishikawa S, Okada K, Saito T. Vasopressin secretion in health and disease. in: The Pituitary Gland, Second edition, Imura H, Ed. Raven Press, New York, pp. 331-350, 1994.

3. Berl T, Schrier RW. Disorders of water metabolism. in: Renal and Electrolyte Disorders, 6th ed. Schrier RW, Ed. Lippincott Williams \& Wilkins, Philadelphia, pp. 1-63, 2003.

4. Slessor A. Studies concerning the mechanism of water retention in Addison's disease and in hypopituitarism. J Clin Endocrinol 11: 700-723, 1951.

5. Oelkers W. Hyponatremia and inappropriate secretion of vasopressin (antidiuretic hormone) in patients with hypopituitarism. N Engl J Med 321: 492-496, 1989.

6. Ishikawa S, Fujisawa G, Tsuboi Y, Okada K, Kuzuya T, Saito T. Role of antidiuretic hormone in hyponatremia in patients with isolated adrenocorticotropic hormone deficiency. Endocrinol Japon 38: 325-330, 1991.
7. Yatagai T, Kusaka I, Nakamura T, et al. Close association of severe hyponatremia with exaggerated release of arginine vasopressin in elderly subjects with secondary adrenal insufficiency. Eur J Endocrinol 148: 221-226, 2003.

8. Greiss SC, Moses AM, Krieger DT. Pituitary tumor associated with inappropriate antidiuretic hormone secretion. Acta Endocrinol 76: 59-66, 1974.

9. Hung SC, Wen YK, Ng YY, Yang WC. Inappropriate antidiuresis associated with pituitary adenoma: Mechanisms not involving inappropriate secretion of vasopressin. Clin Nephrol 54: 157-160, 2000.

10. Kanda M, Omori Y, Shinoda S, et al. SIADH closely associated with non-functioning pituitary adenoma. Endocr J 51: 435-438, 2004.

11. Fujisawa I. Magnetic resonance imaging of the hypothalamoneurohypophysial system. J Neuroendocrinol 16: 297-302, 2004.

(C) 2007 The Japanese Society of Internal Medicine http://www.naika.or.jp/imindex.html 